\title{
Dictynna
}

Dictynna

Revue de poétique latine

1 | 2004

Varia

\section{Approximative Similes in Ovid. Incest and Doubling}

\section{Philip Hardie}

\section{(2) OpenEdition}

\section{Journals}

Electronic version

URL: http://journals.openedition.org/dictynna/166

DOI: 10.4000/dictynna.166

ISSN: $1765-3142$

\section{Printed version}

ISBN: 2-84467-088-1

\section{Electronic reference}

Philip Hardie, «Approximative Similes in Ovid. Incest and Doubling », Dictynna [Online], 1 | 2004, Online since 30 November 2010, connection on 11 September 2020. URL : http://journals.openedition.org/ dictynna/166 ; DOI : https://doi.org/10.4000/dictynna.166

This text was automatically generated on 11 September 2020 .

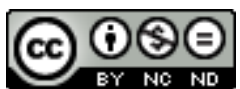

Les contenus des la revue Dictynna sont mis à disposition selon les termes de la Licence Creative Commons Attribution - Pas d'Utilisation Commerciale - Pas de Modification 4.0 International. 


\title{
Approximative Similes in Ovid. Incest and Doubling
}

\author{
Philip Hardie
}

1 This paper is about the pleasures and dangers of getting too close, about a desire to elide difference that operates on both a sexual and a textual plane. My subject is Ovid at his most seriously flirtatious, for this desire is at once the source of typically playful and, as we say, Ovidian - effects of illusion and mistaken identity, and the obsessive urge that keeps the poet writing. This kind of serioludere is a central topic of my book Ovid'spoeticsofillusion ${ }^{1}$; the present discussion may be taken as a supplement to that work.

2 My starting point is a characteristic Ovidian use of simile and comparison, a seemingly pedantic concern to establish the limits of likeness, but in which may also be sensed a desire for the merging of difference in identity, a desire conscious of itself as a forbidden desire. When we use a simile to compare one thing to another we generally proceed on the assumption that phrases of the kind 'just as', 'in no other way' (haudaliter), do not in fact mean that $\mathrm{x}$ is indistinguishable from $\mathrm{y}$. Similes certainly invite us to ponder the exact balance in the 'tussle between discrepancy and fit', as Denis Feeney puts it ${ }^{2}$, but we would in fact feel cheated if fit won out over discrepancy to the point of identity

3 On a number of occasions, by a kind of false naivety, Ovid pretends to a literalmindedness in noting the way in which a simile in fact falls short of identity, and suggests how the conditions of a 'just as' might actually be fulfilled. These similes, which consider, or invite the reader to consider, how the approximation of comparans and comparandum might be completed, may be called 'approximative similes'. Their typical expression is through a qualification in the form of a conditional protasis. The calibration of likeness suits Ovid's role as a careful scholar-poet, alert to fine distinctions and, as we shall see, conscious of particular interpretative quaestiones. At the same time the pressure towards identity that is barely resisted in these precisian formulations betrays the force of the forbidden desires, incestuous and narcissistic, at the psychological heart of Ovid's poetry. 

serving the needs of a precise classification. A botanical example from Georgics 2.131-3 (the citron-tree): ipsa ingens arbos faciemque simillima lauro, / et, si non alium late iactaret

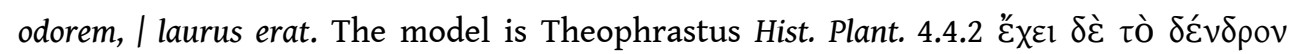

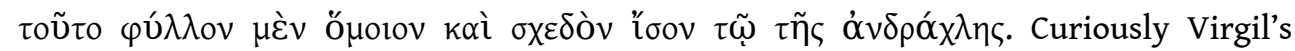
adaptation of the Theophrastan original is itself directed by a mistaken merging of one

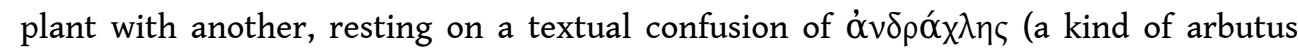
whose leaf the citrus leaf does resemble) with $\delta$ ó $\varphi v \eta \varsigma^{3}$. Virgil expands the Theophrastan model with a conditional clause specifying the particular by which identity is not achieved.

vid speaks the language of (pseudo-) science in a comparison, anticipating the listener's quaestio, that incorporates the product of a metamorphosis within a system of ornithological classification, at Metamorphoses 14.508-9 (the transformed companions of Diomedes) si uolucrum quae sit dubiarum forma requires, I ut non cygnorum, sic albis proxima cygnis.

6 An example of a fully formed approximative simile, with a conditional protasis alerting the reader to a grammarian's quaestio, is found in the third of a list of three similes at Amores 1.7.13-18:

sic formosa fuit; talem Schoeneida dicam

Maenalias arcu sollicitasse feras;

talis periuri promissaque uelaque Thesei

fleuit praecipites Cressa tulisse Notos;

sic, nisi uittatis quod erat, Cassandra, capillis,

procubuit templo, casta Minerua, tuo.

The 'pedantic and objective qualification of the comparison' (McKeown) in line 17, specifying that which differentiates Corinna from Cassandra (unbound as opposed to bound hair), draws attention to the fact that in the traditional account Cassandra does not have her hair bound ${ }^{4}$. Ovid self-consciously adjusts the tradition. The first of the three mythological comparisons, in lines 13-14, also hints at a quaestio : the Arcadian Atalanta, alluded to here, is normally the daughter of Ias(i)us, while Schoeneus is the father of the Boeotian Atalanta.

In what follows I present commentaries on a series of 'approximative similes', and related formulations, in the Metamorphoses. A number of themes and connections will emerge, which will form the subject of a general discussion at the end.

1. Syrinx:

Ortygiam studiis ipsaque colebat

uirginitate deam; ritu quoque cincta Dianae

falleret et posset credi Latonia, si non

corneus huic arcus, ${ }^{5}$ si non foret aureus illi;

sic quoque fallebat. redeuntem colle Lycaeo

Pan uidet...

Met. 1.694-9

The first in the series, is not formally a simile but an imitation and disguise. It is the character Syrinx, rather than the narrator, who constructs a likeness between herself and Diana. At the same time it is the narrator who comments on the difficulty of discriminating between original and imitation. Specifically this is the comment of an internal narrator, Mercury, who tells the story of Syrinx to Argus. Mercury has disguised himself as a simple inhabitant of a rustic world: a god who impersonates a 
stock character of pastoral (that most artificial of genres set in the natural world) is a suitable narrator of a tale about a pastoral nymph who impersonates a goddess. ${ }^{6}$

These disguises pass themselves off as imitations of Virgilian passages about disguises and impersonations. While Argus' 'pastoral invitation' to Mercury at 1.679-81 echoes the end of the first Eclogue, ${ }^{7}$ the setting of the story told by Mercury, 689 Arcadiae gelidis in montibus transfers us to the last poem in the Virgilian collection, Eclogue 10, in which Gallus attempts to play the part of a character on the pastoral stage. ${ }^{8}$ The deception practised by Syrinx herself mimics that practised in Aeneid 1 on Aeneas by Venus disguised as a Carthaginian virgin, and further mistaken by Aeneas either for a goddess, specifically Diana, or for one of Diana's nymphs (Aen. 1.328-9). This comedy of disguise and deception forms part of a larger context in Aeneid books 1 and 4 that forms the crucial intertext for the network of themes that is the subject of this article. In the Homeric model in Odyssey 6 for the meeting of Aeneas and Venus, the character Odysseus practises the narrator's art of simile when he addresses Nausicaa (Od. 6.151-2)

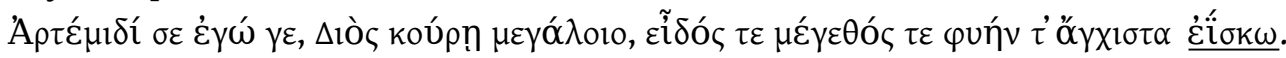
This explicit language of comparison is lacking in the Virgilian imitation, but by a further development of the theme of disguise and likeness, Venus answers Aeneas' surmises as to who she might be not with a plain statement of her true identity, but with the deceptive claim to be a Carthaginian virgin. ${ }^{9}$ When she finally reveals her true self Aeneas complains (Aen. 1.407-8) 'quid natum totiens, crudelis tu quoque, falsis / ludis imaginibus?' The memory of Odysseus' exercise in simile-making may remind us that imago is also a rhetorical term for 'a comparison, simile' (OLD 7b). In getting his distinctions right, Aeneas is also at this point saved from a potentially incestuous encounter, for the meeting with his disguised mother is erotically charged, both inherently and intertextually through allusion to Odyssey 6 and the Homeric Hymn to Aphrodite, as I discuss in detail elsewhere.

The ultimate Homeric model does further work in Mercury's tale of Syrinx. After comparing Nausicaa to the goddess Artemis, Odysseus continues with another essay in constructing a simile (note the formal marker of simile at $0 d .6 .166 \hat{\omega} \varsigma \delta$ ' $\alpha$ v̌ $\tau \omega \varsigma$ ), comparing Nausicaa to a young palm tree that he had seen by the altar of Apollo on Delos (162-8). Ovid's Syrinx dresses up as a goddess, but will be transformed into a plant. Notoriously the whole story of Syrinx presents itself to the reader as an impersonation of another story, being a near double of the story of Apollo and Daphne earlier in Metamorphoses 1. There Daphne, herself innuptae ... aemula Phoebes (1.476), is transformed into another tree sacred to Apollo, the laurel. ${ }^{10}$

In his fussy distinction between the material of Syrinx's bow and the material of Diana's bow, Ovid may hint at a grammarian's quaestio relating to a Callimachean text which, as we shall shortly see, is an important presence in the Ovidian narrative of Daphne, which is the intratextual model for the story of Syrinx. What is Diana's bow made of? In

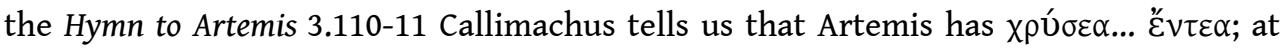

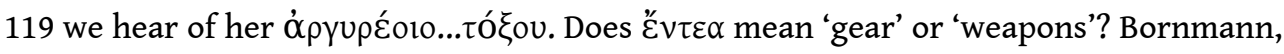
opting for the latter, comments on 119 : 'questo non è l'arco che fa parte dell'armatura d'oro con cui la dea sale sul carro (111), ma è quello stesso per cui Apollo è chiamato

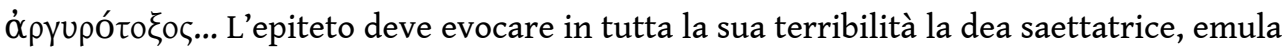
del fratello.' Whether or not this is correct, it is certainly the case that Callimachus' Artemis is caught up in the same game of imitation and emulation as her nymph Syrinx. ${ }^{11}$ Right at the beginning of the Callimachean hymn (6-7) Artemis asks firstly for 
perpetual virginity, and secondly for a multiplicity of names, ív $\alpha \mu$ no $\mu$ o Her next request (8) is for bow and arrows, attributes likewise of her brother. Artemis is twinned with her twin brother Apollo, as the Callimachean Hymn to Artemis is a rivalrous twin of the Hymn to Apollo.

In Ovid's reworking of Callimachean motifs in the story of Apollo and Daphne rivalry becomes entangled with the erotic, and poses an unusually disturbing threat to a nymph's wish for perpetual virginity. Central to my discussion is the claim that, in the artistic and literary spheres, Ovid forges a close connection between rivalry and the erotic. As a text for the metaliterary content of Apollo's erotic pursuit of Daphne we might take Lucretius' apostrophe to Epicurus at 3.3-6 te sequor, o Graiae gentis decus, inque tuis nunc / ficta pedum pono pressis uestigia signis, / non ita certandi cupidus quam propter amorem / quod teimitariaueo. ${ }^{12}$ Or, as Ovid puts it (Met. 1.531-2) utque monebat / ipse amor, admisso sequitur uestigia passu.

Daphne, as we have seen, is (476) aemula Phoebes. Her rivalry of the lifestyle and appearance of Diana soon finds expression via Ovid's literary aemulatio of Callimachus (a poetic 'father'): Daphne's prayer to her father at 486-7 for the gift of perpetual virginity previously assured to Diana by her father (487 'dedit hoc pater ante Dianae')

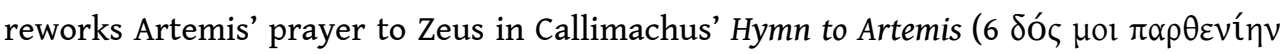

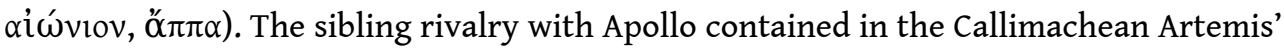

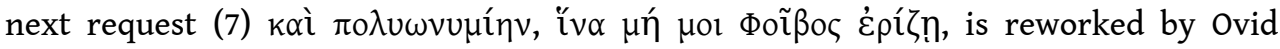
through the answering of the opening allusion to the Hymn to Artemis with allusions to

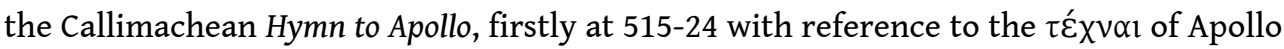
(Hy. Apoll. 42-6), and secondly at the end of the story when the laurel-tree's seeming nod of assent to Apollo's appropriation of itself for his own purposes (566-7) alludes to the sign of Apollo's epiphany in the first line of the Hymn to Apollo. ${ }^{13}$ Apollo's hymn, we might say, wins out in the end over Artemis' hymn, even if Apollo does not succeed in winning full physical enjoyment of the object of his erotic pursuit.

Ovid's Apollo contends with Daphne in a race for sexual possession. Sibling rivalry has turned into something more troubling, a contest to achieve a quasi-incestuous coupling of Apollo with a Diana look-alike. ${ }^{14}$ (Was this indeed what Apollo found irresistible in Daphne, tempted to break the taboo to which Ovid alludes at Am. 2.5.27 when he describes passionate kisses as qualia credibile est non Phoebo ferre Dianam? ) Beautiful lovers are conventionally two of a kind, like Hero and Leander at Musaeus 22-3

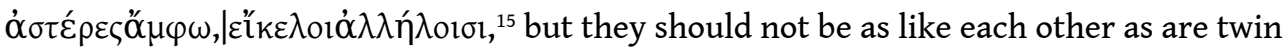
brother and sister. That kind of union is prevented by the metamorphosis of Daphne into the laurel; Apollo's closing prophecy to the laurel that it should always bear evergreen leaves like his own unshorn hair (564-5 utque meum intonsis caput est iuuenale capillis, / tu quoque perpetuos semper gere frondis honores) is a transposition and, in its way, affirmation - but now on Apollo's terms - of Daphne's opening prayer for everlasting (486 perpetua) virginity. Allusion to the prayer that closes another hymn to Apollo, Tibullus 2.5.121-2, reveals that it is indeed the continued virginity of Apollo's sister that is at stake: adnue ; sic tibi sint intonsi, Phoebe, capilli, / sic tua perpetuo sit tibi casta soror. ${ }^{16}$

Incest is averted, to be replaced by an even closer relationship between Apollo and the metamorphosed Daphne. Here I recapitulate considerations developed at greater length in Ovid's poetics of illusion. ${ }^{17}$ The allusion to the nodding laurel at the beginning of the Callimachean hymn hardly marks the acknowledgement by Daphne/'Diana' of Apollo's superiority in the sibling rivalry, for the Callimachean sign marks the presence 
not of Artemis, but of Apollo himself. Apollo's appropriation of the laurel as an attribute for himself and for his own spheres of activity is so total that the laurel becomes in effect a reflection of his own person, as its evergreen leaves are a close metaphor for his unshorn locks, as well as entering the metonymical relationship of a physical contiguity with those locks. In this race the pursued ends up imitating the pursuer, rather than the other way round. The narcissism of Apollo's contemplation of the laurel is of a piece with the self-regarding application to himself of elements of a hymn to Apollo at 515-24. So far from achieving carnal knowledge of Daphne/Diana, Apollo attains a blinkered self-knowledge, in ironic obedience to his own Delphic precept 'know thyself'.

But if the sexually unforced Daphne is, as laurel, forced into the likeness of Apollo, the tree nevertheless remains separate from the god. This separation between Apollo and that which he has, through his actions, brought into being, may be conceptualized in the light of a reading of the metamorphosis of Daphne as the conversion of a puella into the elegiac tenuis liber (549, 'bark'/'book'), the sublimation of sexual desire into art. The relationship between Apollo and this girl-text thus figures the narcissistic and incestuous relationship between author and his book.

\section{Perseus and Andromeda:}

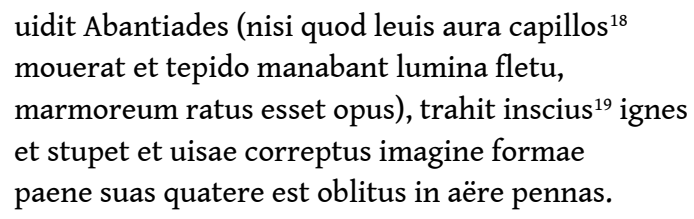

Met. 4.673-7

In this case it is not the reader who is called upon to perform the business of approximation, but a character, Perseus, involved in comparing and discriminating - a character who is at the same time a transparent figure for viewers and readers outside the text. ${ }^{20}$ The primary Virgilian model for the story of Perseus and Andromeda is the quarrel between Turnus and Aeneas for the hand of Lavinia, but for the ecphrastic explorations in the Ovidian narrative we are directed, once again, to the Dido and Aeneas story, to the moment when Aeneas' stupefied gaze turns suddenly from an artistic representation of the Amazon queen Penthesilea to the flesh-and-blood Dido (Aen. 1.490-7). ${ }^{21}$ Perseus' stupor is both the sign of love at first sight, and the conventional reaction to a marvellously lifelike work of art, for an example of which Perseus would have taken this female figure, ifonly her hair and tears had not been in motion. The effect of this stupor or Ě $\kappa \pi \lambda \eta \xi ı$ (literally 'knocking out' from one's senses) is to make Perseus almost forget himself, to forget the need to keep on beating (quatere) his wings. This immobility (which would of course lead, comically, to an instant and rapid downward mobility) would render him a kind of double of the almost immobile Andromeda. This reciprocal objectification of viewed artwork and viewer is well attested in earlier Greek accounts of the process of looking at statues. ${ }^{22}$ Here the quasinarcissisistic bond between viewer and statue is pointed up by echoes of the narrative of Narcissus in the previous book: 4.676 uisae correptus imagine formae= 3.416. At 3.418-19 the motionless Narcissus admires himself as if he were a statue, adstupet ipse sibi uultuque immotus eodem / haeret ut e Pario formatum marmore signum. Narcissus' reflection is as it were a 'simile' of himself, a simile whose subject is a work of art.

21 Motion and motionless distinguish between art and reality in the case of Andromeda. In the case of Narcissus it is sound and soundlessness, 3.460-3: 
... nutu quoque signa remittis

et, quantum motu formosi suspicor oris,

uerba refers aures non peruenientia nostras.

iste ego sum! sensi; nec me mea fallit imago.

The absence of sound is also that which distinguishes statue from real person in Laudamia's attempt to conjure art into real presence at Her. 13.155-6, again with a conditional qualification, here in the form of a paratactic imperative clause:

crede mihi, plus est quam quod uideatur imago:

adde sonum cerae, Protesilaus erit. ${ }^{23}$

Laudamia's attempt to eliminate the gap between artistic representation and reality has earlier been matched by an attempt to turn herself into a double of her absent husband, 41-2 qua possum, squalore tuos imitata labores / dicar et haec belli tempora tristis agam..$^{24}$ Here again the striving to convert representational similarity into identity is the expression of a desire that tends to the narcissistic.

3. Philomela:

ecce uenit magno diues Philomela paratu, diuitior forma, quales audire solemus naidas et dryadas mediis incedere siluis, si modo des illis cultus similesque paratus.

Met. 6.451-4

25 In this example the point of discrimination between the person herself, Philomela, and those in whose image she appears, the nymphs, is not this or that attribute from the sphere of artificial adornment or equipment, as in the case of Syrinx (a bow of horn as opposed to a bow of gold), but the distinction itself between the spheres of nature and culture. That distinction is in fact already operative in the case of Syrinx. Syrinx is a devotee of the goddess of wild nature, a jealous guardian of her own untamed virginity, yet hers is a studied role, 1.694-5 Ortygiam studiis ipsaque colebat / uirginitate deam : studiis 'pursuits', but also 'studies'. colebat (694): her virginity itself a part of her cultus, together with her dress and bow. In the case of Philomela the nature/culture distinction is already present in the description that precedes the simile, dividing the diuitiae of the princess between the artificial wealth of her royal trappings (paratus), and the natural riches of her beauty (forma).

Philomela adds to the store of her artificial adornment the greater wealth of her native beauty. Artificial and natural beauty is the subject of Propertius 1.2, a poem which stages a paragone of natura and cultus in which the costly luxury and commercialism of feminine cultus are held to be incompatible with natural beauty: 5 naturaeque decus mercato perdere cultu. The poem opens with a picture of the girl stepping forth (1 procedere : cf. Met. 6.453 incedere) dressed to the nines in her foreign - non-native and unnatural - ornaments, in strong contrast to the first poem of the Monobiblos which, through the mythological exemplum of Atalanta (1.1.9-16), associates the puella with a nymph-like denizen of the wild woods, and which bestows on the puella a name, Cynthia, that is shared with Diana, goddess of woods and nymphs. In its praise of unadorned beauty Propertius' second poem moves through a series of - highly artificial - comparisons and analogies, concluding 21-2 sed facies aderat nullis obnoxia gemmis, I qualis Apelleis est color in tabulis. Cynthia is to abjure jewels, the rarest and costliest items of feminine cultus and luxuria, and to aspire to a natural beauty compared to the highest form of human art (and one that no doubt commanded the highest prices), the fleshtones of Apelles so skilfully rendered as to create the perfect illusion of nature. 
Propertius 1.2 is an important text for Ovid's treatment of the themes of art and nature, illusion and reality. We will return to Apellean panels; the poem also provides Ovid with a label for the most powerful illusionist in the Metamorphoses, Morpheus: with Prop. 1.2.8 nudus Amor formae non amat artificem cf. Met. 11.634-5 artificem simulatoremque figurae / Morphea.

The verbal artifice of the Ovidian simile would conjure up an exact replica of the real Philomela if the nymphs were decked in the cultus of the princess. With that adjustment the poet's words would have succeeded in converting similarity into identity, as a painting by Apelles deceives the eye into thinking it is that of which it is a representation.

However the unusual qualification quales audire solemus (452) is another barrier interposed between the simile and that of which it is a likeness, placing the nymphs in the mental world of us, Ovid's readers, and apart from the fictional world inhabited by Philomela. Specifically this phrase is an intratextual and intertextual cue, alerting us both to examples of virginal nymphs encountered earlier in the Metamorphoses, the series that begins with Daphne in book one, and also to a Virgilian model for this moment of imagistic delusiveness, once more from the story of Dido and Aeneas - the entry of Dido in Aeneid 1 (497 incessit), compared in a simile to Diana herself, the mistress of the nymphs. ${ }^{25}$ As in the case of the comparison of Syrinx to Diana, the fussy adjustment of the Philomela simile to its comparandum may alert the reader to a grammarian's question. The first-century Virgilian commentator Valerius Probus notoriously complained that the Diana simile at Aeneid 1.498-502 was not an apposite comparison for Dido. Probus' first objection, as reported by Aulus Gellius (Noct.Att. 9.9.12 ff. ), focuses on the lack of fit between the natural world in which Diana (and Homer's Nausicaa) are at home, and the urban sophistication, cultus, of Dido's court:

apud Homerum quidem uirgo Nausicaa ludibunda inter familiares puellas inlocissolis recte atque commode confertur cum Diana uenante in iugis montium inter agrestes deas, nequaquam autem conueniens Vergilium fecisse, quoniam Dido in urbe media ingrediens inter Tyrios principes cultu atque incessu serio, 'instans operi', sicut ipse ait, 'regnisque futuris', nihil eius similitudinis capere possit, quae lusibus atque uenatibus Dianae congruat.

\section{(1)} uirgine Tereus, I quam siquis canis ignem supponat aristis / aut frondem positasque cremet faenilibus herbas. This simile is a close relative of that applied to Apollo when he falls in love at first sight with Daphne at 1.492-5 utque leues stipulae demptis adolentur aristis, / ut facibus saepes ardent, quas forte uiator / uel nimis admouit uel iam sub luce reliquit, / sic deus in flammas abiit. ${ }^{27}$ Imagistically Tereus' first encounter with Philomela is a meeting of Apollo with his sister Diana. This is not inappropriate for Tereus who, typical tyrant as he is, is programmed to commit incest, ${ }^{28}$ and who shortly commits father-daughter incest in his imagination as he converts the spectacle of the filial embraces and kisses bestowed by Philomela on her father Pandion into fuel for his own lawless lust, 475-82... et, quotiens amplectitur illa parentem, | esse parens uellet : neque enim minus impius esset.

\section{Hyacinthus:}

flos oritur formamque capit quam lilia, si non purpureus color his, argenteus esset in illis. 
Met. 10.212-13 which Hyacinthus' blood is metamorphosed is formally very close to the qualification of Syrinx's similarity to Diana at 1.696-7 si non / corneus huic arcus, si non foret aureus illi. Hyacinthus is a boy whose fated death even Apollo cannot prevent (10.203 quoniam fatali lege tenemur), and for which Apollo can find consolation only in the substitutes of song and the inscribed flower into which the boy's blood turns. The surrogate possession of the object of desire replicates Apollo's response to his failure to possess the flesh-and-blood Daphne..$^{29}$ But the pathos of the Hyacinthus episode is also the pathos of the early death of Virgil's Marcellus, Aen. 6.882-6 heu, miserande puer, si qua fata aspera rumpas, I tu Marcellus eris. manibus date lilia plenis, I purpureos spargam flores animamque nepotis / his saltem accumulem donis, et fungar inani / munere. Marcellus himself is trapped by a conditional qualification, if si qua fata aspera rumpas is taken as the protasis to tu Marcellus eris. ${ }^{30}$ Marcellus will be unable to realise his own identity by fulfilling this condition.

Orpheus has already introduced the story of Hyacinthus with a si-clause at Met. 10.162-3, te quoque, Amyclide, posuisset in aethere Phoebus, | tristia si spatium ponendi fata dedissent. ${ }^{31}$ This alludes both to Aen. 6.882 si qua fata aspera rumpas (and may suggest that Ovid read tu Marcellus eris as apodosis to that clause), and to the apostrophe of Icarus in the ecphrasis at the beginning of Aeneid 6, in lines which form a ring with the apostrophe of Marcellus at the end of the book: 30-1 tu quoque magnam I partem opere in tanto, sineret dolor, Icare, haberes. Allusion to the failure of the mythical artist Daedalus, elsewhere renowned for his skill in creating artworks that have magical life, reminds us that when the grieving lover is the god of poetry Apollo, the failure to satisfy desire is also a recognition of the failure of art to call up a fully real presence. Hyacinthus turns into a purple flower like the lily; the dead Marcellus is the recipient of purple lilies. But lilies are normally white, as at Aen. 6.708-9 candida... lilia, or Met. 5.392 aut uiolas aut candida lilia carpit. ${ }^{32}$ Austin ad loc. entertains the possibility of taking purpureos to mean 'simply "bright ", "dazzling ", before deciding that 'it is safer to take the colour here as actual purple, or perhaps bright red'..$^{33}$ Ovid 'corrects' Virgil by restricting lilies to their usual colour, white

As with the wider contexts of the conditional qualifications in the approximative similes applied to Syrinx and Philomela, the wish to draw a clear distinction, here about the colour of flowers, occurs in the context of a narrative of confused and merged identities. Apollo prophesies that the time will come when Hyacinth will share his flower with a fortissimus heros (Met. 10.207-8), a prophecy fulfilled at 13.397-8 littera communis mediis pueroque uiroque / inscripta est foliis, haec nominis, illa querelae. This is too precise a distinction between the meanings of the inscribed AIAI as the letters apply respectively to Aias and Hyacinthus, since the name 'Aias' is itself etymologised from

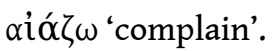

We may also wonder about the nature of Apollo's love for Hyacinthus: same-sex love of a god for a boy, but perhaps also for a boyish version of his own ever-youthful self. Apollo 'forgets himself' (171 immemor ipse sui) in his infatuation for the boy, but at the end of the story it is his own grief that is stamped on the only physical reminder of Hyacinthus, 215 ipsesuosgemitus foliis inscribit. The hyacinth is turned into as self- 
regarding a monument to the absent object of desire as had been the laurel in the parallel story of Apollo and Daphne. flosque nouus scripto gemitus imitabere nostros (206): the flower becomes a narcissistic reflexion, a faithful textual imitation, forever mindful of the god's own grief. ${ }^{34}$

5. Adonis:

laudaret faciem Liuor quoque: qualia namque corpora nudorum tabula pinguntur Amorum, ${ }^{35}$ talis erat, sed, ne faciat discrimina cultus, aut huic adde leues aut illi deme pharetras.

Met. $10.515-18^{36}$

The description of the new-born Adonis includes the most complex example of the approximative simile, and the one where are most clearly articulated issues both of artistic (verbal and visual) likeness, and of confusions of identity and of sexual relationships. Adonis is like a beautiful painting, but a work of art that represents the naked and unadorned body of Amor. Not quite unadorned, however, since the naked Amores are distinguished from the baby in its completely naked - and natural - state by an item of cultus, Cupid's quiver (cf. Syrinx's bow). Once again we catch echoes of the opposition of natura and cultus in Propertius 1.2: with nudi Amores compare Prop. 1.2.8 nudus Amor formae non amat artificem ; but the Ovidian naked Loves are painted on what might be the 'Apellean panels' of Prop. 1.2.22.

9 Even before we reach the simile, the baby Adonis' beauty has been presented as an object for the connoisseur of art, for Liuor's criticism is properly directed at verbal or visual works of art, rather than at naturally occurring objects. ${ }^{37}$ The problem with Adonis is not simply one of distinguishing between him and Cupid, but of distinguishing between nature and art. This problem is his inheritance as the greatgreat grandson of Pygmalion and his statue; is it surprising that a member of this family should be as pretty as a picture? Adonis is miraculously born of a tree, which in his case supplies not wood for the painter's panels, but a flesh-and-blood child. His mother Myrrha had undergone the opposite transformation to that of her greatgrandmother the statue, from soft living flesh to a hard unfeeling object, in fulfilment of her prayer to be excluded from the worlds of both the living and the dead - as the supremely lifelike work of art is suspended uncannily between the animate and the inanimate.

's metamorphosis is the punishment for her incest with her father. Here too the sins of the mother are visited, allusively, on the son. When he grows up, as he does outstripping his own superlative beauty as infant, Cupid becomes the object of Venus' passion. Not only does Venus fall in love with a man who as a baby was the look-alike of her own son Cupid, but the mythological mechanism of this infatuation is an accidental prick from an arrow of Cupid himself, inflicted while the boy-god was kissing his mother. Kiss and arrow-prick hint at an incestuous act between mother and son, and it is appropriate that the object of Venus' desire should be Cupid's double. ${ }^{38}$

41 A further confusion follows, of a kind with which we are now familiar in connection with passages containing approximative similes. In her obsequium to her beloved as he ranges the mountains and woods in the hunt, Venus dresses up as Diana, Met. 10.536 fine genus uestem ritu succincta Dianae, indistinguishable from Syrinx at 1.695 ritu... cincta Dianae. ${ }^{39}$ This role is now played by its original interpreter, the Venus of Aeneid 1. She leaves her normal world of feminine cultus to enter Diana's domain of untamed nature, 
Met. 10.533-5 adsuetaque semper in umbra / indulgere sibi formamque augere colendo, / per iuga, per siluas dumosaque saxa uagatur. We have been told that Venus' infatuation with Adonis is revenge for his mother's incestuous passion (524 matrisqueulcisciturignes): a lover who looks like Cupid avenges Cupid's part in making Myrrha fall in love with her father, and implicitly challenges Cupid's protestation that he had no part in that business, 10.311-14 ipse negat nocuisse tibi sua tela Cupido, / Myrrha, facesque suas a crimine uindicat isto : / stipite te Stygio tumidisque adflauit echidnis / e tribus una soror.

Distinctions, and the failure to maintain distinctions, point to further Virgilian intertexts in the story of Dido and Aeneas. Virgil's readers will remember that the workings on Dido of Venus and Cupid are not readily to be distinguished from the actions of Allecto on Amata in Aeneid 7, as Oliver Lyne points out. ${ }^{40}$ If Cupid's denial of complicity is disingenuous, then it is fitting revenge that the real Cupid's erotic wounding of his mother in the Adonis episode should be truly unintentional, 10.526 inscius extanti destrinxit harundine pectus. Virgilian models continue to operate: Cupid's unwitting arrow wound replicates that inflicted figuratively on Dido by Cupid's halfbrother Aeneas at Aeneid 4.69-72 qualis coniecta cerua sagitta, I quam procul incautam nemora inter Cresia fixit / pastor agens telis liquitque uolatile ferrum / nescius. The effect of the wound on the deer is to send her fleeing through the wilderness, 72-3 illa fuga siluas saltusque peragrat / Dictaeos, like Venus at Met. 10.535. Later Aeneas will protest, with how much conviction it is for the reader to decide, that it was never his intention to hold out the torches of marriage for Dido, Aen. 4.338-9 nec coniugis umquam / praetendi taedas. ${ }^{41}$ Aeneas' cousin Cupid also protests that he was not guilty of a misuse of torches, Met. 10.312 facesque suas a crimine uindicat isto.

M.D. Thomas has shown that Adonis' revenge looks to a Euripidean as well as a Virgilian model. ${ }^{42}$ At the end of the Hippolytus Artemis promises her dying favourite that she will take revenge on Aphrodite by punishing the mortal most dear to her with her own unerring (and consciously aimed) bow (1420-2). The unnamed victim is most readily to be identified as Adonis. Ovid's Venus acts out a literary imitation that at the same time operates in the imitative mode of revenge, for Venus' change of behaviour realises the wish of the Euripidean Phaedra, as a result of Aphrodite's vengeance on Hippolytus for neglecting herself in favour of Artemis, to leave the closed spaces of the house and go wandering over the mountains to join in the hunt of her stepson (Hippol. $215 \mathrm{ff}$.). Ovid thus condemns Venus to act out the part of her own victim in the Euripidean play, and this 'revenge' is even more satisfying in that her quasi-incestuous relationship with Adonis, the double of her own son Cupid, mirrors Phaedra's quasiincestuous desire for her stepson Hippolytus. ${ }^{43}$

As we have seen, the problems with Adonis go back to his ancestor Pygmalion. Pygmalion succeeds in completely effacing the boundary between nature and art. He creates the shape of a woman the like of which has never been seen in nature (10.248-9 qua femina nasci / nulla potest), but whose art is so consummate that it conceals itself behind the appearance of life (250 quam uiuere credas; 252 ars adeo latet arte sua). The boundary between art and nature is policed by a conditional qualification at $251 \mathrm{et}$, si non obstet reuerentia, uelle moueri [credas]. But this conditional qualification itself seems to elude delimitation. As Anderson notes ad loc. reuerentia is 'puzzling at first, for we might think our " reverence » is invoked. ${ }^{44}$ We would then translate 'if your sense of respect did not prevent it, you might believe that it wished to move/be handled', taking credas as apodosis to obstet. This is the sacred sense of respect that would restrain the 
viewer of the Venus of Cnidos from treating the statue as if it were the proper object of desire for a mortal. Alternatively we could ascribe the reverentia to the statue itself, translating 'you would believe that she wished to move/be handled, did not a sense of modesty prevent her', taking uelle moueri as apodosis to obstet. In this case the protasis actually increases the approximation between motionless art and moving life, since the statue's immobility coincides with an effect of the mental state of the real person. ${ }^{45}$ The boundary between art and reality (id quod obstat), between text and world of the reader, is wearing very thin, and will be effaced entirely at the moment when the obstacle between desire and its fulfillment is overcome (obstare is often used by Ovid of obstacles in the lover's way). ${ }^{46}$

The actual metamorphosis of ivory statue into flesh and blood woman is precipitated by Pygmalion's desire to overstep the distinction between simile and reality:

'sit coniunx, opto', non ausus 'eburnea uirgo'

dicere Pygmalion 'similis mea' dixit 'eburnae. '

Met. $10.275-6$

Venus grants this prayer by turning simile into identity: his wife is not like the ivory maiden, she is the ivory maiden, who becomes his wife by a magic which cancels the difference between the substances of ivory and bodily flesh through metamorphosis of the one into the other. The elimination of the gap between simile and reality is the verbal equivalent of the visual illusion of reality created by a statue or painting.

The confusion of representation and reality, on both verbal and visual levels, corresponds to a confusion at the level of sexual relationships. Pygmalion's love is both narcissistic and incestuous. Narcissus falls in love with an image that is a naturally occurring representation of himself, 3.463-4 nec me mea fallit imago: / uror amore mei. Pygmalion falls in love with an image of his own making, 249 operisque sui concepit amorem. This is an artificial image, but not a representation of any external reality, for we have been told (248-9) that its form is not that of any woman in nature. The statue, then, is in Pygmalion's own likeness, in the sense that it represents his response to the flawed nature of women as they are in nature. It is also his 'daughter', in the sense that an artist is the 'father' of his creations. ${ }^{47}$

The close link between the confusion of linguistic and sexual boundaries ${ }^{48}$ is repeated in the history of Pygmalion's great-granddaughter Myrrha. Orpheus apostrophises Myrrha at 10.346-8 et, quot confundas et iura et nomina, sentis ? | tune eris et matris paelex et adultera patris? | tune soror nati genetrixque uocabere fratris? The union with her father Cinyras is accompanied by a staged reworking of Pygmalion's prayer to Venus, with its distinction between eburnea uirgo and similis eburnae. Firstly Myrrha replies to her father's inquiry as to whom she wishes to take as a husband (364-5) 'similem tibi' dixit; at ille / non intellectam uocem conlaudat. Secondly, the nurse reacts to her realisation of the true nature of Myrrha's desire thus: 429-30 'uiue' ait haec, 'potiere tuo' - et non ausa 'parente' / dicere conticuit. The word itself, without qualification, is finally uttered at the moment of incestuous intercourse, 467-8 forsitan aetatis quoque nomine 'filia' dixit : / dixit et illa 'pater', sceleri ne nomina desint. Cinyras is not 'like my father', he is 'my father'. In this episode is revealed most fully the connection in Ovid's writing between an anxiety about incest and a concern for the correct linguistic labels.

Diana, disguise, incest

In conclusion I wish to outline two larger frameworks within which to consider the confusion of art and nature that runs through the passages examined above. The first 
relates to the recurrent presence of Diana in the series: Daphne, Syrinx, Philomela are all females who might be confused with Diana, or with a follower of Diana. In the stories of Syrinx, Philomela, and Adonis there is a confusion between the realms of Diana and Venus: Syrinx and Philomela as virginal Diana look-alikes arouse desire through a vision of unattainability; Adonis strays fatally from the embrace of Venus into the hunt of Diana, and is accompanied by a Venus disguised as Diana. Diana as goddess of the wilds is opposed to Venus the goddess of cultus, of the female toilette: a similar opposition relates Diana to her brother Apollo, most schematically in what might be viewed as the foundational story in the series, the Apollo and Daphne where, as Gerlinde Bretzigheimer puts it 'In dem Quasi-Zwillingspaar Phoebus... und aemula Phoebes ... stoßen mit venatrix und artifex Gegenwelten aufeinander. Alles an Apollo zeugt von cultus-Orientiertheit und Urbanität. ${ }^{49}$ Behind all of these Ovidian variations on the theme lies the Virgilian figure of Venus disguised as a virgin huntress, an inhabitant of the world of Diana, an apparition programmatic for the confusion of the realms of Venus and Diana that brings Dido to her tragic end. ${ }^{50}$

Jean-Pierre Vernant has stressed the function of Artemis/Diana as a divinity who presides over the proper articulation of roles and domains, 'a divinity of the margins with the twofold power of managing the necessary passages between savagery and civilization and of strictly maintaining the boundaries at the very moment they have been crossed. ${ }^{51}$ In a poem of metamorphoses, where boundaries are constantly under threat, she is hard put to it to ensure that proper limits are observed. In some cases the boundary confusions result from offenses against Diana (Callisto, Actaeon), but in other cases the Ovidian Diana seems to have an uncertain control over the boundaries that she should be policing.

51 The most important of these boundaries is that between the wild and cultivated, and it is above all in the hunt that Diana controls this boundary. 'On the frontier of two worlds, marking their limits and guaranteeing their proper articulation by her presence, Artemis presides over the hunt... She sees to it that the boundaries between the wild and the civilized are permeable in some way, since the hunt allows passage from one state to the other. ${ }^{52}$ The stories of Callisto and Actaeon show what happens when a nymph or mortal offends the goddess; they are transformed from hunter to hunted, placed fatally on the wrong side of the wild/cultivated divide.

This boundary between the wild and the cultivated becomes of crucial importance for Ovid's conception of himself as a poet, as will be immediately clear when for the terms 'wild' and 'cultivated' are substituted 'nature' and 'art', or natura and cultus. Ovid is constantly aware of the highly artificial quality of his art, and at the same time fascinated by the power of this artifice to mirror or create the appearance of nature. ${ }^{53}$ He strives to break down the barrier between art and nature, so that eventually art comes to mirror itself in nature (or vice versa). But Ovid is also aware that this mirroring in the end is just that, and not the true achievement of the (impossible) passage from the artificial into the natural. When art claims to succeed in effacing the distinction between itself and nature, in truth it succeeds only in collapsing the structured differential between the two terms into a narcissistic or incestuous joining of like with like.

53 This role of Diana as policewoman of the boundary between nature and art explains what might otherwise seem the curious fact that perhaps the most pointed Ovidian formulation of the paradoxes of art and nature is found in the description of Diana's 
grotto in the Actaeon episode, at Met. 3.158-9 simulauerat artem / ingenio natura suo, further developed by Apuleius in the ecphrasis of the Actaeon grotto, and summed up in the motto ars aemula naturae. ${ }^{54}$

As we have repeatedly seen, within the economy of the Metamorphoses much of the complex of themes under consideration in this article is generated out of the foundational episode of Apollo and Daphne. As lustful male and virginal female Apollo and Daphne are polar opposites, but from other points of view they are too close to each other. There is an element of contrivance in Daphne's self-presentation: not simply an unselfconscious Naturkind, she models herself on Diana, 476 innuptaeque aemula Phoebes, through an exercise of a simple cultus that aligns her with the artifex Apollo, who thinks of Daphne's beauty in terms of the cultus that is the subject of instruction in the Ars amatoria. ${ }^{55}$ It is through the cultivation of the Diana-look that she appears to Apollo in the likeness of his twin sister.

This brings me to the second of my two frameworks for thinking about the relation of art and nature in Ovid. Apollo's pursuit of Daphne, the look-alike of his own twin sister, suggests incest as a central figure for Ovid's own artistic practices of mimesis and imitatio. If this secret is well disguised in the first book of the Metamorphoses, it is almost recklessly blown to the winds in the stories of Pygmalion and his great-great-grandson Adonis in book ten, subjects of the self-regarding song of Orpheus, the thinly disguised double of Ovid himself.

In a discussion of the story of Byblis' love for her brother Caunus in Metamorphoses 9, a near doublet of another of Orpheus' subjects in book 10, Myrrha's love for her father Cinyras, Micaela Janan reads the theme of incest as a figure for 'poetic selfreferentiality', in the sense of the text's Maeandering returns on itself as Ovid repeats himself, rewriting the Heroides in Byblis' letter to her brother. 'The poem replicates itself.., limiting creative options to the already known - the literary realization of incest. ${ }^{{ }^{56}}$ This is interesting, but limited as an account of the possibilities of incest as a figure for poetic creation. More fertile is John Irwin's Freudian reading of the themes of 'doubling and incest, repetition and revenge' in the novels of William Faulkner. Irwin is indeed concerned with the way in which Faulkner's writings repeat themselves, but this relation of text to text is subordinated to the relationship between the artist and his work, a relationship constituted of the three major elements of 'incest, autoeroticism, and self-destruction'. ${ }^{57}$ Irwin thus relates the author as a living subject to his books, the detached and lasting objects into which the author uses up his biologically mortal self in a 'transmission through the author's books' that is fertilized by 'the phallic generative power of the creative imagination'. ${ }^{58}$ This might be described as a metamorphosis of natural procreation into a world of art. Faulkner also explores the conversion of the other, as object of desire, from biological reality into work of art, the feminine double of the artist's masculine self. Faulkner makes recurrent allusion to Ovid's Pygmalion and Narcissus: for example in the novel Mosquitoes the sculptor Gordon compensates for his hopeless love for a woman by sculpting the headless, armless, legless torso of a girl. ${ }^{59}$ (She won't be able to run away.) Flesh and blood is abruptly replaced by self-reflection in Soldier's Pay where a character aptly named Januarius Jones stands in front of a door locked by a girl that he has been pursuing, leaving him to contemplate in the door's 'polished depths the fat white blur of his face'. 
57 poet's, and the reader's, relationship to the text. Equally well traced are the intertwinings of the experiences of Narcissus with the story of Pygmalion, an episode which offers itself even more insistently as a reflection on Ovid's processes of composition and on the experience of his reader. Pygmalion's desire is incestuous as well as narcissistic, and is the tainted source of recurrent incest in later generations. But, I have argued, incest seeps out repeatedly in other passages of the poem that touch closely on one of Ovid's most constant obsessions, the relationship between art and nature, representation and reality.

\section{BIBLIOGRAPHY}

Anderson, W.S. Ovid's Metamorphoses. Books 6-10, Norman, Oklahoma

Archibald, E. (2001) Incest and the medieval imagination, Oxford

Austin, R.G. (1955) P. Vergili Maronis Aeneidos liber quartus, Oxford

Austin, R.G. (1977) P. Vergili Maronis Aeneidos liber sextus, Oxford

Barthes, R. (1977) Sade, Fourier, Loyola, transl. R. Miller, London

Bettini, M. (1999) The portrait of the lover, transl. L. Gibbs, Berkeley, Los Angeles, London

Bornmann, F. (1968) Callimachus : Hymnus in Dianam, Florence

Bretzigheimer, G. (1994) ‘Diana in Ovids Metamorphosen’, Gymn. 101: 506-46

d'Alessio, G.B. (1996) Callimaco Inni Epigrammi Ecale, Milan

Fabre, J. (forthcoming) 'Ovide et la naissance du genre pastoral. Reflexions sur l'ars noua et la hiérarchie des genres (Mét., II, 668-719)'

Feeney, D.C. (1992) ‘ "Shall I compare thee..? » Catullus 68b and the limits of analogy', in Woodman and Powell (1992): 33-44

Goold, G.P. (1992) 'The voice of Virgil. The pageant of Rome in Aeneid 6', in Woodman and Powell (1992) 110-23

Hardie, P. (1994) Virgil Aeneid book IX, Cambridge

Hardie, P. (1997) 'Virgil and tragedy', in C. Martindale (ed.) The Cambridge companion to Ovid, Cambridge

Hardie, P. R. (2002) Ovid's poetics of illusion, Cambridge

Hinds, S. (1987) The metamorphosis of Persephone. Ovid and the self-conscious Muse, Cambridge

Hunter, R. and Fuhrer, T. (2002) 'Imaginary gods? Poetic theology in the Hymns of Callimachus', in F. Montanari (ed.) Callimaque (Entretiens sur l'antiquité classique 48), Geneva: 143-87

Irwin, J.T. (1996) Doubling and incest, repetition and revenge. A speculative reading of Faulkner, expanded edition, Baltimore and London

Dictynna, 1 | 2004 
Jacobsen, G.A. (1984) 'Apollo and Tereus: parallel motifs in Ovid's Metamorphoses', CJ 80: 45-52

Janan, M. (1991) 'The labyrinth and the mirror: incest and influence iin Metamorphoses 9', Arethusa 24: $239-56$

Knox, P.E. (1986) Ovid's Metamorphoses and the traditions of Augustan poetry, Cambridge

Kost, K. (1971) Musaeus Grammaticus. Hero etLeander, Bonn

Lausberg, H. (1960) Handbuch der literarischen Rhetorik, Munich

Lyne, R.O.A.M. (1987) Further voices in Vergil's Aeneid, Oxford

McCabe, R.A. (1993) Incest, drama and nature's law 1550-1700, Cambridge

McKeown, J.C. (1989) Ovid: Amores. vol. ii. A commentary on book one, Leeds

McKeown, J.C. (1998) Ovid : Amores. vol. iii. A commentary on book two, Leeds

Murgatroyd, P. (1994) Tibullus Elegies I, Oxford

Murgatroyd, P. (2001) ‘Ovid's Syrinx', CQ 51: 620-3

Mynors, R.A.B. (1990) Virgil Georgics, Oxford

Otto, A. (1890) Die Sprichwörter und sprichwörtlichen Redensarten der Römer, Leipzig

Rank, O. (1992) The incest theme in literature and legend. Fundamentals of a psychology of literary creation, transl. G. C. Richter, Baltimore and London

Riposati, B. (1942) L'elegia a Messalino di Albio Tibullo, Milan

Rosati, G. (1983) Narciso e Pigmalione. Illusione e spettacolo nelle Metamorfosi di Ovidio, Florence

Shackleton Bailey, D. R. (1986) ‘Tu Marcellus eris', HSCP 90: 199-205

Steiner, D.T. (2001) Images in mind. Statues in archaic and classical Greek literature and thought, Princeton and Oxford

Thomas, M.D. (1998) ‘Ovid's Orpheus: immoral lovers, immoral poets’, MD 40: 99-109

Vernant, J.-P. (1982) 'From ÆEdipus to Periander: lameness, tyranny, incest in legend and history', Arethusa 15: 19-37

Vernant, J.-P. (1991) 'The figure and functions of Artemis in myth and cult', in Mortals and immortals. Collected essays, Princeton: 195-206

Vinge, L. (1967) The Narcissus theme in western European literature up to the early nineteenth century, Lund

Woodman, T. and Powell, J. (eds.) (1992) Author and audience iin Latin literature, Cambridge

\section{NOTES}

1. Hardie (2002).

2. Feeney (1992) 36.

3. Athen. 3.83d, quoting Theophrastus, has $\delta \alpha \dot{\alpha} \varphi v \eta \varsigma \dot{\alpha} v \delta \rho \alpha ́ \alpha \lambda \eta\rceil$, the gloss possibly having slipped

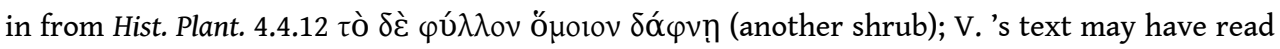

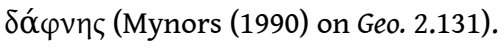

4. See McKeown (1989) ad loc. There was also disagreement as to whether Cassandra had her hands bound (as at Aen. 2.405-6: see Austin on 406) or not (the usual version, to which Ovid 
reverts at Met. 13.410-11). Mckeown (on Am. 1.7.17-18) refers to the description of Daphne Met. $1.477 \mathrm{ff}$. to make the point that 'the wearing of a uitta need not necessarily imply an ordered coiffure'; note further that in that passage Apollo is also in the business of making fine distinctions between different female appearances, 497-8 spectat inornatos collo pendere capillos / et 'quid, si comantur?' ait : Apollo desiderates the cultus that is the differentia between Philomela and the nymphs in the simile at 6.454 (see below). Ovid appears elsewhere as the objective 'scientific' - classifier of feminine beauty: at Am. 1.14.9-10 he again fine-tunes a description of hair (an interest he shares with Apollo), nec tamen ater erat neque erat tamen aureus ille / sed, quamuis neuter, mixtus uterque color; the ultimate impossibility of accurate description is echoed in the language used of the product of Salmacis' metamorphic union with Hermaphroditus at Met. 4.379 neutrumque et utrumqueuidetur, a confusion that is the result of a narcissistic, and perhaps almost incestuous, desire. At Am. 2.5.41 a series of three similes applied to Corinna's blush concludes his erat aut alicui color ille simillimus horum : for the verbal formulation McKeown (1998) compares inter alia two passages in which questions of identity are at issue: (i) Met. 7.12-13 (Medea's comment on her erotic furor) 'nescio quis deus obstat' ait 'mirumque quid hoc est, / aut aliquid certe simile huic, quod amare uocatur'. Medea will find out soon enough, like the speaker at Ecl. 8.43 nunc scio quid sit Amor - the god we learn four lines later (Ecl. 8.47-50) who taught a mother (Medea) to stain her hands with the blood of her children: for Virgil's self-allusion to this passage of Ecl. 8 in a context of problematic identity see n. 9 below; (ii) Her. 2.146 aut hoc aut simili carmine notus eris (Phyllis composes an indictment of Demophoon in her own epitaph). Knox (1995) ad loc. sees in this a 'realistic touch': 'Phyllis does not expect to be able to dictate the text of the epitaph ... on her tomb'; but the fussy qualification also alerts the reader to the ways in which Phyllis' carmen is both like and unlike the carmen of the poet Ovid, the real composer of this couplet. The words are identical, but the two (verbally) identical versions are separated by the impermeable barrier between the fictional world of Phyllis and the world of the poet: as I shall argue, this kind of approximative comparison is often triggered by Ovid's interest in the gap between representation and that which is represented.

5. A corneus arcus is also the test of identity at Am.1.8.48 (Penelope tests the suitors) qui latus argueret corneus arcus erat, with the double entendre on arcus= 'bow' or 'penis': Dipsas alludes to the version of a promiscuous Penelope, the mother by 'all' the suitors of none other than Pan (see McKeown (1989) ad loc. ): curiously then, in his attraction to the bearer of a corneus arcus Pan is drawn to a punning version of his own origin! Reference is made to the cornu durius inguen of Pan's Italian double Faunus at Fasti 2.346 in the course of another story of mistaken identity, Faunus' attempted rape of Hercules in woman's dress. The Homeric Penelope's testing of the suitors with Odysseus' bow is an important intertext for the 'proof' of Ascanius' manhood against Numanus' charges of Trojan effeminacy in Aeneid 9 (see Hardie (1994) 199). Ascanius vows to Jupiter a bullock, an animal surrogate for his own budding masculinity, Aen. 9.629 iam cornu petat et pedibus qui spargat harenam: cornu petere 'aim at with a bow' is also what Ascanius does to Numanus: the actual description of Ascanius' stretching of the bow might carry sexual overtones for a reader whose innocence had been compromised by reading too much Ovid, Aen. 9.622-3 neruoque obuersus equino / contendit telum.

6. The impersonations extend further: Argus himself is not a real cowherd in the sense that his charge, the metamorphosed Io, is not a real cow, a point made by Fabre (forthcoming).

7. With 679 hoc poteras mecum considere saxo cf. Ecl. 1.79 hic tamen hanc mecum poteras requiescere noctem; note also umbram/e at line-end at Met. 1.681 and Ecl. 1.83.

8. Cf. Ecl. 10.15 gelidi... Lycaei ; 42 hic gelidi fontes. Syrinx is a naias among hamadryades (690-1); both classes of nymphs appear in $E c l .10(10,62)$.

9. Ovid's disguised Mercury tells a story about disguise: in her (true) narrative of Dido's earlier history the disguised and deceiving, but ultimately self-revealing, Venus tells a tale of deception and its discovery: with Aen. 1.352-3 multa malus simulans uana spe lusit amantem. / ipsa sed in somnis 
inhumati uenit imago cf. 407-8 'quid natum totiens, crudelis tu quoque, falsis / ludis imaginibus ?' With 'crudelis tu quoque' Aeneas slips into the role of an impersonated character in the Eclogues, the deceived lover of the song of Damon (Ecl. 8.48-50), who has unmasked the true nature of the god of love, 43 nunc scio quid sit Amor, after being the dupe of an erotic deception comparable to the deception of Dido after the death of Sychaeus, Ecl. 8.41 ut me malus abstulit error. Dido will later unmask another erotic pretender, the dissimulator Aeneas, in whom she will recognize a child of the hard rocks like his cousin Amor (Aen. 4.366-7 duris genuit te cautibus horrens / Caucasus : cf. Ecl. 8.43-5 duris in cotibus illum / aut Tmaros aut Rhodope ... edunt). If Rank (1992) 375 is right, the story of Dido, Sychaeus, and Pygmalion may also conceal brother-sister incest: note the ambiguity of 350-1 securus amorum / germanae.

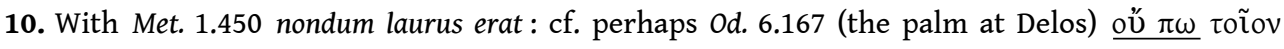

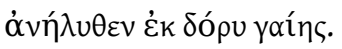

11. For the Callimachean Artemis as 'pendant to her brother' see Hunter and Fuhrer (2002) 161-4.

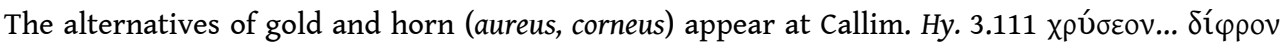

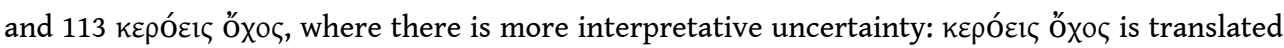
by d'Alessio (1996) as 'il carro di corno', by LSJ as 'drawn by horned cattle'. For rivalry with Apollo in the sphere of poetry see Theocr. 7.100-1: Ovid's Apollo and Daphne episode is motivated by a rivalry between Apollo and Cupid in the sphere of archery, but with a transparent metapoetic reference to rivalry between the genres of epic and elegy: see Nicoll (1980).

12. Lucretius here attempts to separate imitatio and aemulatio, two moments in the intertextual relationship that are rarely so cleanly separable in ancient theory and practice as here. Lucretius uses the venatic image of hunting dogs in pursuit of the truth at 1.404-9; in the De rerum natura all intellectual pursuit and imitation is ultimately under the sign of Venus.

13. See Hardie (2002) 48.

14. Bretzigheimer (1994) 518-19 refers to the 'Quasi-Zwillingspaar Phoebus... und aemula Phoebes'.

15. See Kost ad loc. on the novelistic topos of 'Gleichheit der Liebenden'; Hardie (2002) 142 n. 78. Bettini (1999) 101-8 on lovers as 'twins' or 'siblings'.

16. Tib. 2.5 opens with a summons of Apollo that may allude to the opening of Callimachus' Hymn to Apollo, and ends with the poet's reinforcement of Artemis' own prayer for chastity at the beginning of Callimachus' Hymn to Artemis: this sequence is inverted in Ovid's Apollo and Daphne.

17. Hardie (2002) 47-8.

18. Cf. 1.529 et leuis impulsos retro dabat auracapillos: yet another throwback to Daphne - laur(e)a.

19. Cf. Met. 10.526 inscius extanti destrinxit harundine pectus (discussed below), both moments linked to Aeneas' first sight of Dido.

20. On the ecphrastic themes in the story of Perseus and Andromeda see Hardie (2002) 178-86.

21. Hardie (2002) 183-6.

22. See Steiner (2001) 198-204 'Relations of Reciprocity'.

23. With the form of the apodosis compare also Met. 13.895-6 qui, nisi quod maior, quod toto caerulus ore, / Acis erat (spoken by a grieving lover). Her. 13.156 may also call to mind the Virgilian tu Marcellus eris (Aen. 6.883): on Ovid's further use of that passage see the discussion of Hyacinthus

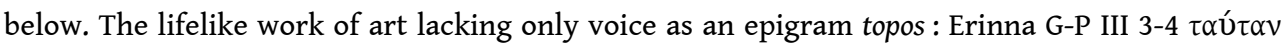

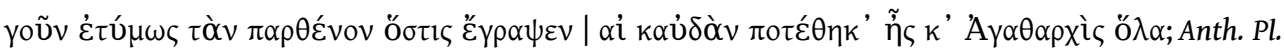
326.

24. See Hardie (2002) 133.

25. See Hardie (2002) 260-1.

26. Servius on Aen. 1.497 makes explicit the general consideration by which Virgil is to be defended: quam [comparationem] uituperant multi, nescientes exempla uel parabolas uel comparationes adsumptas non semper usquequaque congruere, sed interdum omni parte, interdum aliqua conuenire. Servius' distinction has precedents in earlier classifications of simile, as totum simile, impar, 
dissimile, contrarium, and doubtless Ovid's self-conscious dealings with similes reflects an awareness of the grammatical and rhetorical tradition: cf. e.g. Quintil. IO 5.11.30-1... esse aliquid minus simile, ut simia homini et marmora deformata prima manu, aliquid plus, ut illud, Non ouum tam simile ovo (Otto (1890) no. 1318.1). Probus complains that Dido and Diana are not alike as two eggs. See also Feeney (1992) 36, referring to Lausberg (1960) 230-4. Feeney's essay brilliantly reveals Catullus as a predecessor for Ovid's archly self-conscious dealings with similes.

27. On the parallelism between the two similes see Jacobsen (1984).

28. See Vernant (1982).

29. Hardie (2002) 63-4.

30. Norden takes the si-clause as a meld of conditional and wish, as at 6.30-1 tu quoque magnam / partem opere in tanto, sineret dolor, Icare, haberes. For other ways of construing the clauses see recently Goold (1992) 121.

31. According to Prop. 3.18.33-4 Marcellus did end up in the stars, quo Siculae uictor telluris Claudius et quo / Caesar, ab humana cessit in astra uia.

32. The alternative identification of the flowers picked by Proserpina as either violets or white lilies itself shows Ovid playing the role of 'pedantic commentator' on contradictory passages in the Homeric Hymn to Demeter, according to Hinds (1987) 78-80.

33. With ref. to Pliny NH 21.25 purpurealilia called narcissus; Norden also refers to Theophr. Hist.

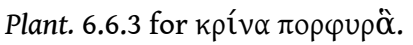

34. Modern historians of Greek religion view Hyacinthus as a pre-Greek god or hero who 'merged with Apollo probably before the end of the bronze age' (OCD3 734).

35. Cf. Am. 1.14.33-4 illis contulerim, quas quondam nuda Dione / pingitur umenti sustinuisse manu, a reference to Apelles' Venus Anadyomene, at the moment of the goddess's birth. McKeown (1989) ad loc. thinks Ovid has in mind the reference to Apelleae tabulae at Prop. 1.2.22, a poem of central importance for Ovid, as we have seen; McKeown also suggests that 'Venus' naked beauty at her birth may have been a standard paradigm in attacks on excessive ornatio'.

36. For the models in Hellenistic epigram for the simile see Knox (1986) 58; Hardie (2002) $187 \mathrm{n}$.

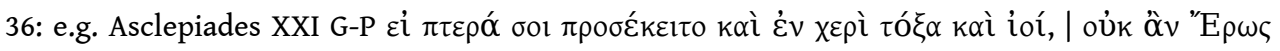

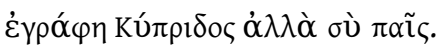

37. Livor as literary critic: McKeown (1989) on Am. 1.15.1-2; as art critic: Met. 6.129-30.

38. See Hardie (2002) 187-8.

39. Cf. also 9.89 nymphe ritu succincta Dianae, bringing on the Cornucopia at Achelous' banquet.

40. Lyne (1987) 13-27.

41. 'Praetendi is both literal and metaphorical', Austin (1977) ad loc., referring to 172 coniugium uocat, hoc praetexit nomine culpam. Aeneas and Dido are engaged in a lethal contest of definitions. What does constitute a real wedding? At Aen. 4.166-8 a divinely manipulated nature imitates the cultural institution of the wedding ritual.

42. Thomas (1998).

43. For the relationship as incestuous see Her. 4.129-46, where Phaedra appeals to the example of Jupiter and Juno, like Byblis at Met. 9.497-9, and like Byblis at Met. 9.558-60 argues that their incestuous union could be concealed under the signs of affection legitimate between close relatives.

44. On the ambiguity here see also Steiner (2001) 207 n. 71.

45. For the trick cf. the (unmoving) woven image of Catullus' Ariadne, stunned by emotion into a marmoreal stillness, Cat. 64.60-7.

46. Am. 1.11.8; Ars 2.720; 3.619; Her. 2.21; 18.35; 21.40; Met. 7.145-6 sed te, ne faceres, tenuit reuerentia famae : / obstitit incepto pudor; 8.75 .

47. Ovid as the 'father' of his books of poetry: Trist. 3.1.66; 3.14.11-12; Pont. 1.1.21-2. 
48. On the close connection between linguistic and sexual confusions see McCabe (1993) 70, referring to inter alios Barthes (1977) 137-8 suggesting that the family is "no more than a lexical area', and incest is merely 'a surprise of vocabulary', a primarily semantic crime.

49. Bretzigheimer (1994) 518-19.

50. Hardie (1997) 321-2.

51. Vernant (1991) 204.

52. Vernant (1991) 198.

53. The best treatment of this topic is Rosati (1983).

54. Apul. Met. 2.4 uuae faberrime politae... quas ars aemula naturae ueritati similes explicuit.

55. Bretzigheimer (1994) 518-24.

56. Janan (1991) 242.

57. Irwin (1996) 163.

58. Irwin (1996) 159

59. See Irwin (1996) 16.

60. See Irwin (1996) 167.

\section{AUTHOR}

\section{PHILIP HARDIE}

Corpus Christi College, Oxford 